\title{
Regulations on PPP contracts in Vietnam: Status Quos and Solutions
}

\author{
Nguyen Quoc Toan ${ }^{1 *}$, Nguyen Dinh Phong ${ }^{1}$, Nguyen Viet Huong ${ }^{1}$, Nguyen Thi Tuyet Dung ${ }^{2}$, \\ Nguyen Tan Vinh ${ }^{3}$ \\ ${ }^{1}$ Faculty of Construction Economics and Management, National University of Civil Engineering, \\ Hanoi, Vietnam \\ ${ }^{2}$ Urban Management Faculty, Hanoi Architectural University, Vietnam \\ ${ }^{3}$ Institute of Construction Economics, Vietnam
}

\begin{abstract}
PPP investments have been in practice in Vietnam for more than 20 years, yet, many shortcomings and constraints have been revealed. This paper analyzes applicable legal regulations on Public-private partnership contracts of investment in Vietnam, and demonstrates barriers encountered by parties, particularly private sector, including discrepancies and noncoherence among legal documents resulting in losses, wastes of resources; absence of standard agreements/ contracts making negotiations and contract signing hard to conclude; insufficient clarity in provisions about concessioning, and responsibilities, among others. The analysis, hence, suggests how to deal with the situation by amendments, supplements to provisions on the agreements between public and private partners.
\end{abstract}

\section{Introduction}

To reduced burden of state budget, enhanced investment resources for investment in infrastructure, an approach of building the partnership of public and private sectors has been applied in the name of Public Private Partnerships (PPP).

Over more than 20 years of practice, total 336 PPP projects have been implemented, in the forms of BOT, BTO, BT in Vietnam, with total investment of approximately 1,609,335 billion VND [1]. In terms of forms of contract, BOT and BT projects are most common, including 140 BOT projects (41.67\%) with total investment of 1,138,538 billion, and 188 BT projects $(55.95 \%)$ with total investment of 465,118 billion VND. The remainders include 5 BOO projects (1.49\%) with total investment of 2,116 billion VND, 01 BLT $(0.3 \%)$ with total investment of 423 billion VND, and 02 BOT-BT ( $0.6 \%$ ) with total investment of 3,140 billion VND. Most BT projects have been implemented at local level (172 out of total 188 projects) [1]. As a result, in order to improve the value for money of PPP investments, it is important to have in place appropriate legal framework and provisions on the relationship among relevant stakeholders. Such relations are established by legal means of Investor-State contracts.

\footnotetext{
* Corresponding author: toannq@nuce.edu.vn
} 


\section{Overview}

There is a wide range of literature, domestically and internationally, relevant with InvestorState contracts in the mode PPP, which all emphasizes on the importance of clear and specific regulations on contacting.

R.Roberto (2004) pointed out the contributing factors to the success of PPP projects, specifically: the essential role of a clear and effective legal environment. This factor allows contracts to be identified firmly and enables parties to understand the boundaries of interactions; and a due diligence of a project by both parties [2].

The United Nations Economic Commission for Europe (UNECE) (2008) could prove that the lack of process and procedures has become the major obstacle to the broader application of PPP. UNECE explained the rational of "a roadmap" of PPP policies with clear goals; development of a transparent legal framework, and introduction of principles, priorities to the development of such framework. The study also pointed out the risks associated with PPP project implementation, and how such risks should be managed by governments. UNECE also put emphasis on transparency, neutrality, and non-discrimination during PPP participation and implementation [3].

N.Pongsiri (2002) showed the increasingly important role of PPP, and the fact that to well exercise this relation, it is necessary to anchor on a stable, reliable legal system, covering the sphere of ownership rights, contracts, disputes, responsibilities and legality [4]. Z.Xueqing (2005) introduced 5 groups of factors: enabling investment climate; economic growth; resources to cater project demands; strong financial package; proper risk allocation [5]. Yescombe (2007) looked into general policy issues generated from within the public sector. And the fact that PPP policies should be promulgated with financial bindings, and be cautious to avoid misinterpretation, or ignorance of PPP financial agreements, which may underpin the benefits of PPP [6]. C. M. Rui , B. Sanford (2011) analyzed the contractual provisions of public-private partnership (PPP) related to infrastructure services. They studied about EU, PPP, institutionalized PPP (mixed company) and a purely contractual PPP. A purely contractual PPP comprise concession, affermage, and management contracts. Some features of PPP contracts include the sharing of responsibilities and risks between the public and private partners. The study itself showed that there have been a lot of researches about PPP in developing countries, which is characterized by the lack of transparency, the lack of professionalism in the implementation and management of PPP projects, and the lack of procedures to prevent corruption. Their paper also studied the general aspects of PPP contracts, and their strengths and limitations, contract design issues and reasons why contracts fail [7].

E. Eduardo et al. (2014) analyzed PPP financial contracts and the Special Purpose vehicle (SPV), which stimulates and effectiveness and connectivity. Because PPP projects are of large scale, require independent management, SPV is specifically suitable form of institution. Where a PPP contract is designed precisely, high cost of capital can be the price for effective advantages of PPP over public delivery [8]. Sarmento Joaquim (2014) described Portugese experience in PPP renegotiation, and came to a conclusion that: a better institutional framework, which is defined by low political risk, solid legal set of principles, and reduced corruption, tends to bring down the probability of renegotiations. Evidence shows that in high times of corruptions, many renegotiations took place [9].

N.T. Lang (2008) provided systematic analysis and assessment of legal regulations about BOT contracts, pointed out their fundamental progresses compared with the past ones; along with limitations and shortcomings of the legal framework and actual implementation of those provisions; explained objective and subjective causes to the current status quos [10]. T.T. Son (2015) identified the list of risk factors in PPP road transport infrastructure development projects, taking into account the socio-economic, legal and political conditions in Vietnam. 
The results provided hints for sharing of risk factors among parties to PPP contracts [11]. N.V. Bao et al (2016) pointed out that State and private sector are partners to implement a project, provide a service at the demand of the citizens. The partnership of the state is reflected in 2 aspects: (1) the State as an entity entering into a contract with the private entity, and (2) the State as a participant to the project. This requires the State to wear the hats of an Investor and a state authority to amicably settle the conflict of interests between the state and a private party [12]. N.T.T. Hien (2020) pointed out that in order for PPP projects to work, it is important to have a mechanism of sharing responsibilities and risks between the relevant parties. Whereas, the study emphasized the strong political commitment and continuous support of the government to establish an institutional and legal framework, create trust of the private sector; the State needs to have enough capacity to implement, and manage PPP projects, and share risks properly [13].

The above literature have not looked specifically into the provisions in a PPP investment contract in Vietnam, not updated to the latest regulations. Hence, the research team will analize the actual provisions on PPP investment contracting in Vietnam, and out the shortcomings and recommendations for amendment.

\section{Current regulations on PPP investment contracts in Vietnam}

\subsection{Current regulations on PPP investment contracts}

Regulations on investment contracts are seen as a fundamental substance of investment laws in relation to PPP modality. At present, a part from the Civil Code which dictates general provisions about contracts, there are few regulations on PPP investment contracts in Investment Law [14] and Public Investment Law [15], PPP Investment Law [16] (which is hereinafter referred to as PPP Law), the Decree Ref. No. 63/2018/ND-CP regarding investments using PPP [17] (hereinafter referred to as Decree 63), as follows:

\subsubsection{Regulations about names of different PPP investment contracts}

PPP investment contracts are defined in Decree 63, Article 3, Clause 2, as "project contracts" [17]. In the PPP Law, it dictates that "PPP project contracts are written agreements between an authority and an investor, a PPP company about concessioning Investor, PPP company by the state to implement a PPP project in line with provisions of this Law" [16]. However, law makers have not introduced an official academic concept of project contracts, but a list contracts referred to as project contracts, instead.

Comparisons of applicable regulations in Vietnam and India, China shows that every country has a different approach of providing for PPP investment contracts. Nevertheless, they share a standard form contract for investment PPP, and contracted parties shall abide to the default terms in the standard form contract. The application of a standard form contract sets many advantages for standard contracting, but also limits the flexibility of contractual interactions and implementation. This is a remarkable obstacle in those countries because of potential major changes in policies, demand, financing, risks during the many years of project implementation. The fact that parties can not amend the content of default standard form contracts may lead to less satisfactory project effectiveness.

\subsubsection{Regulations on classification of PPP investment contracts}

PPP related literature and documents by international organizations such as the International Monetary Fund (IMF), the World Bank (WB), the Asian Development Bank (ADB) have 
pointed out a number of PPP models in the world [18], such as: BOT, BOO BOOT, O\&M, BT. The above contracts can be grouped in 3 categories:

(i) User fee contracts (e.g.: BOT, BTO, BOO, O\&M);

(ii) Service-Quality based payment Contracts (e.g.: BLT, BTL);

(iii) Public resources in exchange for works contracts.

According to Vietnamese regulations, parties can enter into either of the following PPP investment contracts (or project contracts) [16]: BOT, BTO, BOO, BTL, BLT, O\&M, and Mixed contracts (a combination of any of the above contracts). Obviously, according to current regulations, BT contracts no longer belong to the category of PPP project contracts.

However, reality shows that BOT and BT contracts were the 2 most popular project contracts in Vietnam before PPP Law was issued (in 2020).

Comparison with China's regulations on PPP project related contracts shows that there are 3 key payment mechanisms, these include: government payment, user fees and VGF. They are applied in different PPP projects. Public transport such as expressways, flyovers, and metros, public utility infrastructure for water and heat supply often run a loss of user fees. Meanwhile, VGF refers to economic subsidies from the government to project enterprises to fill the gaps of PPP, when user fees can not make up for the input costs and reasonable profits.

Regarding PPP investment contracts, different countries have relatively different legal regulations on PPP. Laws in the Philippines dictate different kinds of contracts and new contracts can be proposed. Laws in South Korea only govern BTO, BTL, BOO contracts. Laws in India, meanwhile, provide for the following types of contracts: BOT Annuity Model and BOT Toll Model, mostly used in road and freight transport, and railway transport. Energy sector tends to apply BOO contracts. A part from popular procurement contracts such as results-based contract/management contracts, and energy procurement contracts, other types known also include BOLT, DBFOT and BOOT [19].

Hence, that legal regulations provide for many types of PPP contracts enables investors to select the most appropriate form of investment, which fits investors' conditions, capability and encourages investors' participation.

\subsubsection{Regulations on the content of project contracts}

Contract content is a result of clauses negotiated and agreed by parties, which includes terms on rights and obligations of parties when engaged in the contractual relation. Under Decree 63, Article 41 [17] and PPP Law, Article [16], parties can negotiate on the following basic content, in part or in full:

- Objective, scope, location, timing, and project schedule; construction period;

- Requirements of technical specifications, technologies, project quality, products or services delivered;

- Total investment capital and financial plan of the project;

- Value, conditions, ratios and progress of the implementation of the portion of state responsibility in a PPP project (if any);

- Compensation, land acquisition, resettlement;

- Construction process; Requirements for inspection, supervision; quality management during construction; final check and taking over, final payments of completed works;

- Risk and responsibility sharing among parties to the contract, including competent state authority (ies), authorized organization (with signed authorization), and the investor; principles of dispute settlement; force majeure etc.

- Investment incentives and Bonds (if any);

- Law governing the relation of project contracts, relevant contracts and dispute settlement mechanism; 
- Effectiveness and validity of project contracts;

- Principles, conditions of amendment, supplementation, and termination of project contracts; transfer of rights and obligations in accordance with the project contract; - etc.

Based on the above-mentioned basic content of a project contract, Ministries, ministerial agencies provide for details of standard form contracts, which are suitable with the project requirements in their respective area, sector of authority.

\subsubsection{Regulations on signing and implementation of project contracts}

Pursuant to the PPP Law, Article 49 [16] and Decree 63, Article 39 [17], based on the approval of evaluation of the selected investor, and outcomes of negotiations, contract finalization, the competent state authority shall arrange for the signing of a project contract either of the following ways:

- The competent state authority and the Investor sign a project contract. In this case, the Competent state authority, Investor and the project enterprise (if any) sign a document regarding permission granting to the project enterprise to receive and exercise the Investor's rights and obligations in line with the provisions in the project contract. This Document is an integral part of the project contract. With this approach, signatories to the project contract comprise of the competent state authority (public partner) and the Investor (private partner). The project enterprise, though not being the signatory to the project contract, is in the position to exercise the rights and obligations of the Investor as per the project contract. To make this work, law makers have formulated the regulation in a way that an agreement (as an addendum to the contract) is designed, reflecting the good wills of signatories of the project contract to assign the project enterprise to exercise the rights and obligations of the Investor in line with the project contract.

- The Investor and the project enterprise form a party to sign the project contract with the competent state authority. In this approach, signatories to the project contract comprise of a competent state authority (the public partner), Investor and the project enterprise (the private partner). Because both the Investor and the project enterprise are key signatories to the contract as one private partner, they shall share the same rights and obligations, and are relevant to the exercise of the rights and obligations of the private partner in line with the project contract.

\subsubsection{Regulations on public disclosure of project contracts}

Public disclosure of project contracts is a mandatory procedure to ensure the publicity, transparency, and assurance of access to information by the society and communities. Public disclosure of project contracts is the responsibility of the competent state authority, which shall be done on the national procurement network system within 07 working days of the signing date of the project contract [16], [17].

Where project contracts are amended and supplemented and result in the need to revise the content to be disclosed, then the competent state authority shall update such information on the national procurement network system within 07 days of signing contract addendum.

\subsubsection{Regulations on concessioning the rights and obligations of the Investor in line with the project contract to other individuals, organizations}

Within the period of project contract implementation, should the Investor and project enterprise be able to or not to continue project implementation, such rights and obligations can be transferred to another entity. 
By laws, the Investor reserves the rights to concession the rights and obligations in part or in full, in line with the project contract signed to another lender or Investor after the completion of the civil works in the civil works component of the project or after stepping in to the operational phase of the project without a civil works component. Concessioning in part or in full of rights and obligations, in line with the project contract, shall not affect the objective, scope, technical specifications, progress of the project implementation, and shall meet the investment and operation conditions in accordance with the legal regulations on investment, and other conditions as agreed in the project contract [16], [17].

The agreement on concessioning rights and obligations of the Investor in line with the project contract shall be made in writing and signed by parties to the project contract and the transferee. Lenders participate in concessionaire negotiation in line with the loan agreement. Where the transfer of rights and obligations in line with the project contract causes changes to the business registration license, then, the project enterprise shall undertake necessary procedures to amend their business registration license accordingly, in conformity to the legal provisions on enterprises. Where the lender is the entity who receives the rights, and obligations in line with the project contract transferred from the Investor, project enterprise, the lender may receive, in person, or authorize other organization with sufficient capacity to receive in part or in full the rights and obligations transferred by the Investor, project enterprise where the Investor or project enterprise fails to exercise such obligations provided for in the project contract or in the loan agreement.

\subsection{Limitations, shortcomings of current regulations on PPP investment contracts}

Desk reviews of current regulations on PPP investment contracts points out the following limitations and shortcomings:

First, current legal framework reveals discrepancies in names of contracts between the Investor, project enterprise and a competent state authority for the implementation of a PPP investment project.

Existing legal regulations about construction contracts include: Civil Code Ref. No. 91/2015/QH13 [20]; Procurement Law Ref. No. 43/2013/QH13 [21]; Civil Engineering Code Ref. No. 50/2014/QH13 [22]; Decree 63/2014/ND-CP promulgates in details a number of articles of the Procurement Law regarding the selection of contractors [23]; Decree Ref. No. 37/2015/ND-CP providing specifically about construction contracts [24]; Circular Ref. No. 03/2015/TT-BKHĐT on providing specific provisions on preparing the invitation to bid on construction works. [25].

The above mentioned legal regulations do touch upon the basic content of construction contracts. However, every legal regulation do mention different aspects of construction contracts, points agreed upon and points in conflict, and points that need to be supplemented.

There are discrepancies among different regulations, specifically, in terms of how contracts are named for the implementation of a PPP investment project, which show the different interpretation of concepts, different approaches and problem solving of law makers in relation to the contract signed by parties for the implementation of a PPP project.

In view of the author, the noun "project contracts" does not clearly reflect the nature of the contract, the signatories and its purpose. The definition of a project contract under the Decree 63, Article 3, Clause 2 is not clear enough, apart from the list of project contracts, such as BOT, BTO, BT contracts v.v. Hence, the typical features reflecting the nature of the contract of this type - which is an investment partnership contract signed by a public partner and a private partner for the purpose of designing, building, renovating, operating and exploiting public infrastructure and services. Therefore, it is necessary to identify the nature and revise the title of this type of contract to be more scientific and precise, more 
comprehensible and easier to implement, towards clear nature and special features of the contract in contrast to other types of contract in the fields of investment and economic operation. Particularly, it is important to ensure the consistency in nominating this contract in relevant legal regulations for enhanced feasibility and transparency of laws.

Second, current regulations on project contracts do not clearly reflect whether the signing and implementation of the contract shall construe to the provisions in the Civil Code or they are subject to special principles? The reason we, as authors, raise this question is because a mandatory contract shall ensure parties' freedom of good will, and equality in rights and obligations. However, one party in the project contract is a state authority. Hence, there will be certain exceptions. In many cases, the Investor may not be fully aware of their true position in contracting. This leads to the less flexible contractual terms due to the will of the state party, affecting the rights of the Investor, in general and the effectiveness of the project, in particular.

Third, the existing regulations about project contracts are not strict to prevent evasion of laws in implementing PPP projects for favored interests and public assets appropriation, or losses, wastes, and forming of interest groups. In reality, there are many "gaps" in legal regulations about BT projects in Vietnam, bringing about "super profits" for Investors. Particularly, BT projects give way for land handing over without auctions of land use right, and no procurement procedures engaged can cause losses, and wastes of public assets, and also a place of corruption and wrong doings.

Decree 63 promulgates many modes of payments to the Investor in a BT contract by "using the value of land use right, work office premises, infrastructures, in line with the legal regulations on the management, and utilization of public properties. Concessioning of operation of works and services in accordance with the specialized laws and regulations", which is a relatively effective and attractive enough to draw the interest of private capital. However, the regulation reveals many shortcomings and limitations in practice. Specifically, that land valuation for calculating compensation is not close to the market situation causes many negative reactions and prolonged complaints, and insufficient state budget revenue collection. During audits of PPP projects, the State Audit of Vietnam concluded that pubic asset valuation (including land use rights) in BT projects under the Panel of Appraisal price valuation, which is subject to the approval of Provincial People's Committee, without price auctioning, can not help reflect the public and transparent payments to the Investor [26]. That land use right valuation is way below the market price definitely cause losses to the public properties and benefit Investor.

It is not feasible to put land use right to an auction (which then is transferred to the Investor for netting in BT projects), when the Investor has to participate in the auction and eventually does not win the price in the auction, that all brings up a question of whether the land use right can be transferred to the Investor, who loses auction position?

As such, PPP investment is a contract-based investment and making complete of legal regulations on PPP contracts is very crucial to promote investment activities. It is the limitations in the regulations about PPP contracts are the main cause to high likelihood of disputes among parties.

Fourth, existing regulations are not consistent in the standard form of project contracts to ensure relevance to special attributes of each type of project contracts, to create uniformity in the application of PPP investment projects.

In principle, project contracts are long-termed, so contractual terms and conditions shall be both strict and flexible to ensure the legal rights and benefits of parties. Standard form of project contract is not yet available in current legal regulations in Vietnam. This is one of the reasons why contractual negotiations are prolonged. Besides, PPP project contracts, so far, show the fact that contract developers have limited capacity, less experience in project financing, project legality, risk assessment and allocation, and imprecise investment capital 
total calculation, etc. resulting in not strict provisions on the responsibilities and duties of related parties.

Fifth, transfer of rights and obligations in line with the project contract. According to Decree 63, Article 43, Clause 3, transfer of rights and obligations shall be in writing and signed by parties to the project contract and the transferree. The lender participates in the negotiation of the concessionaire in line with the loan agreement. However, review of relevant provisions to the Article 39, signatories to the project contract comprise of 02 parties only, specifically the Competent state authority and the Investor (unlike the provision in Clause 2, where the Investor and project enterprise form One party), then project enterprise is not considered one party to the project contract. Thus, does this concessionaire agreement require certification of the project entreprise?

In principle, it is a must to attain certification and consent of the project enterprise, because the project enterprise is an entity with the rights and obligations relevant to the project contract (regardless whether they are a separate party or just an entity acquiring and implementing the rights, and obligations of the Investor). According to general principles of the Civil Code, transfer of obligations shall be consent to by the right holder. Therefore, it is necessary to attain certification, consent of the project enterprise, i.e. all entities that bear the rights and obligations of the project contract, not just the "Parties".

Sixth, regarding transfer of assurances upon transfer of rights and obligations in line with the project contract. During project implementation, the state authority shall request Investor to issue securities for the investment. Under Decree 63 Article 47, it dictates: "Competent state authority and the Investor shall agree on the form, value, effective validity of the project contract implementation security in accordance with the applicable procurement laws" [17].

However, the above analysis about transfer of rights and obligations in line with the project contract shows that there are not yet any regulations on the transfer of securities, except for the single article in Decree 63 and the provision about Lenders participating in transfer negotiation as per the Loan agreement. It is dictated in the Civil Code 2015, Articles Nos. 368 and 371 regarding transfer of securities upon transfer of rights and obligations, specifically as below [20]:

- Where a right to demand the performance of a secured civil obligation is transferred, the transfer of the right to demand shall include the security.

- Where a secured civil obligation is transferred, the security shall terminate, unless otherwise agreed.

PPP projects are related to the state budget, hence, securities for project performance shall be strictly provided for. The gap of specific provisions upon transfer of rights and obligations in line with the project contract should be filled.

\section{Solutions}

In our view, amendment and supplementation of regulations about contracts signed between a public partner and a private partner should focus on the following specific issues:

Firstly, legal regulations relevant to PPP mode investments shall promulgate uniformly about the names of contracts signed by Investors, project companies and competent state authorities as "PPP investment contracts", as per the nomination under the Investment Law 2014, Article 3, Clause 8. The reason for this change is the terminology "project contracts" does not clearly reflect the nature of this type of contract, who is the signatories and what it is aimed at.

The definition of a project contract as indicated under Decree 63, Article 3, Clause 2, is not clear enough when it only list different types of contracts deemed to be project contracts, such as BOT, BTO etc. Hence, the typical features reflecting the nature of the contract of this type - which is an investment partnership contract signed by a public partner and a private 
partner for the purpose of designing, building, renovating, operating and exploiting public infrastructure and services. Therefore, it is necessary to identify the nature and revise the title of this type of contract to be more scientific and precise, more comprehensible and easier to implement, towards clear nature and special features of the contract.

Second, it is necessary to clearly regulate that the signing, and performance of PPP investment contracts (or project contracts) shall conform to the basic principles provided for in the Civil Code on signing and implementing contracts, ensuring publicity and transparency, accessibility during the application of laws and regulations.

Third, to supplement regulations on standard form contracts. To develop and apply standard form contracts for PPP projects, it is important that competent authorities work with each other and reach consensus at strategic and legal basis level. Besides, it is important to have legal regulations amended on this regard, which then function as the foundation for the development and introduction of standard form contracts by competent state authorities.

A PPP contract is normally performed for a long period of time (20 years or 30 years), no amendments to it may cause burdens to the PPP project given changes in laws and socioeconomy. Where a standard form contract is provided for by Vietnam laws, it should be given certain level of flexibility for, for instance, possible amendment of the contract to ensure best possible performance of the project, or possible review of contractual terms every 5 years. The period of 05 years is suitable with the interval of land price framework adjustment cycle in Vietnam.

Fourth, it is necessary to revise relevant regulations to transfer of rights and obligations in line with the PPP contracts in a way that transfer of rights and obligations in line with the project contract shall attain agreement of obligors, including the state authority party, the Investor and the Project enterprise. Besides, it is necessary to supplement with detailed provisions on transfer of securities to be in conformity with the provisions under the Civil Code and to secure the rights of the parties.

\section{Conclusions}

Based on review of PPP mode contracts in the World, the analysis of current regulations on PPP contracts in Vietnam (in terms of naming, categorization, substance, provisions on signing and performing a contract, public disclosure, transfer of contract), and their comparison with those in similar countries, the group of authors have pointed out the limitations, shortcomings in relation to PPP mode contracts. These include discrepancies in the legal framework, non-strict provisions on signatories to the contract, insufficient content, the absence of a standard form contract, and contrasting provisions about the transfer of rights and obligations, etc. They form grounds for the 4 solutions introduced by us for the making complete of the management of public private partnership investment contracts towards sustainable development.

\section{References}

1. Ministry of Transport, Synthesize reported data of 47 units (06 ministries and 41/63 localities), Hanoi, Vietnam (2018)

2. R. Roberto, Resource Book On PPP Case Studies, The European Commission (2004)

3. UNECE, Guidebook on Promoting Good Governance in PublicPrivate Partnerships, United Nations, Geneva (Switzerland), United Nations Economic Commission for Europe (2008)

4. N.Pongsiri, Regulation and public-private partnerships, International Journal of Public Sector Management, 15(6), 487-495 (2002) 
5. Z.Xueqing, Critical Success Factors for Public-Private Partnerships in Infrastructure Development, Construction Engineering and Management, 131(1), 3-14 (2005)

6. Yescombe, Public-Private Partnerships, Principles of Policy and Finance, Published by Elsevier Ltd (2007)

7. C. M. Rui , B. Sanford, Public-Private Partnership Contracts: A Tale of Two Cities with Different Contractual Arrangements, Public Administration, 89(4), 1585-1603 (2011)

8. E.Eduardo et al., Finance and Public-Private Partnerships, Conference "Financial Flows and Infrastructure Financing", Sydney, Australia (2014)

9. J.Sarmento, Public private partnerships, Tilburg: Center, Center for Economic Research (2014)

10. N.T.Lang, BOT contract in current law and practical application in Vietnam, $\mathrm{PhD}$ thesis, Ho Chi Minh University of Law, Vietnam, (2008)

11. T.T. Son, Research on risk allocation in the form of public-private partnerships for road traffic infrastructure development in Vietnam, $\mathrm{PhD}$ thesis, University of Transport anh Communication, Vietnam, (2015)

12. N.V. Bao, N.Q. Toan, S.V. Hoai, The influencing factors and the role of the State affecting the success of the PPP model in road infrastructure development investment, Journal of Construction Economics, 1/2016, 04-09 (2016)

13. N.T.T. Hien, N.Q. Toan, PPP for sustainable urban development towards green growth, Vietnam Journal of Construction, 2/2020, 48-52 (2020)

14. National Assembly, Law No.67/2014/QH13 on investment, Vietnam, (2014)

15. National Assembly, Law No.49/2014/QH13 on public investment, Vietnam, (2014)

16. National Assembly, Law No.64/2020/QH14 on Public-Private Partnership Investment, Vietnam, (2020)

17. Government, Decree No. 63/2018/NĐ-CP on investment in the form of public-private partnership, Vietnam, (2018)

18. ADB, "Public-private partnership (PPP) handbook", Retrieved 11/15/2020, https://www.adb.org/documents/public-private-partnership-ppp-handbook , (2008)

19. Werneck, B., \& Saadi, M. (Eds.), The public-private partnership law review, Law Business Research Limited (2015)

20. National Assembly, Law No.91/2015/QH13, The Civil Code, Vietnam, (2015)

21. National Assembly, Law No.43/2013/QH13 on bidding, Vietnam, (2013)

22. National Assembly, Law No.50/2014/QH13 on the construction, Vietnam, (2014)

23. Government, Decree No. 63/2014/ND-CP, detailing the implementation of several provisions of Law on Bidding regarding the selection of contractors, Vietnam, (2014)

24. Government, Decree No.37/2015 on construction contract, Vietnam, (2015)

25. Ministry of Planning and Investment, Circular No. 03/2015/TT-BKHĐT dated 06/5/2015, on providing specific provisions on preparing the invitation to bid on construction works, Vietnam, (2015)

26. State audit office of Vietnam, Document No.140 /KTNN-PC dated 28/9/2018, Hanoi, (2018) 